\title{
Nanomaterial Based Biosensors for Detection of Viruses Including SARS-CoV-2: A Review
}

\author{
Ayushi Bisht $^{1} \cdot$ Abhishek Mishra $^{2} \cdot$ Harender Bisht $^{3} \cdot$ R. M. Tripathi ${ }^{2} \mathbb{C}$
}

Received: 28 March 2021 / Accepted: 17 August 2021 / Published online: 8 November 2021

(c) The Nonferrous Metals Society of China 2021

\begin{abstract}
The COVID-19 outbreak led to an uncontrollable situation and was later declared a global pandemic. RT-PCR is one of the reliable methods for the detection of COVID-19, but it requires transporting samples to sophisticated laboratories and takes a significant amount of time to amplify the viral genome. Therefore, there is an urgent need for a large-scale, rapid, specific, and portable detection kit. Nowadays nanomaterials-based detection technology has been developed and it showed advancement over the conventional methods in selectivity and sensitivity. This review aims at summarising some of the most promising nanomaterial-based sensing technologies for detecting SARS-CoV-2. Nanomaterials possess unique physical, chemical, electrical and optical properties, which can be exploited for the application in biosensors. Furthermore, nanomaterials work on the same scale as biological processes and can be easily functionalized with substrates of interest. These devices do not require extraordinary sophistication and are suitable for use by common individuals without high-tech laboratories. Electrochemical and colorimetric methods similar to glucometer and pregnancy test kits are discussed and reviewed as potential diagnostic devices for COVID-19. Other devices working on the principle of immune response and microarrays are also discussed as possible candidates. Nanomaterials such as metal nanoparticles, graphene, quantum dots, and CNTs enhance the limit of detection and accuracy of the biosensors to give spontaneous results. The challenges of industrial-scale production of these devices are also discussed. If mass production is successfully developed, these sensors can ramp up the testing to provide the accurate number of people affected by the virus, which is extremely critical in today's scenario.
\end{abstract}

Keywords SARS-CoV-2 Electrochemical sensors · Nanomaterials · Colorimetric detection · Microarray-based sensors · Impedimetric biosensors

\section{Introduction}

In 2019, a cluster of patients with an unknown cause of pneumonia-like symptoms was reported [1]. World Health Organization (WHO) identified the causative pathogen to be the novel Coronavirus, now named SARS-CoV-2 [2]. The SARS-CoV and MERS-CoV viruses are of similar origins $[3,4]$. The novel coronavirus consists of a single-stranded positive RNA enclosed inside a capsid with club-shaped

R. M. Tripathi

rmtripathi@amity.edu; rmtripathi02@gmail.com

1 Amity Institute of Biotechnology, Amity University, Noida 201303, India

2 Amity Institute of Nanotechnology, Amity University, Noida 201303, India

3 Reliance Industries Limited, Motikhavdi, Jamnagar 361140, India glycoproteins on its envelope $[4,5]$. It contains the largest genome in its family and can cause infection without the requirement of any enzyme [5]. The virus can be transmitted through person-to-person contact and aerosols of infected individuals. Although the mortality rate varies in different countries depending on several factors, in March 2020, it was recorded to be $3.7 \%$ worldwide [6]. Ever since its outbreak, it has been a strenuous task to contain and combat this virus as the host cell factors such as ACE2 and Ezrin, which assist the virulence remained evasive for some time [7]. Relentless efforts of scientists all over the world are focused on diverse strategies to develop a potential vaccine. However, the process is time taking as it is calculative and requires several trials [8]. It is quite evident that the number of cases detected is still not completely reliable because of the paucity of tests conducted. Therefore, in times of crisis like these, it is very essential to detect the viruses in the 
quickest possible way to avoid spreading and taking control of the pandemic.

Different types of sensors and biosensors are being developed to detect the coronavirus within minutes. One of the main reasons for the uncontrollable outspread of the virus is time-consuming tests such as real-time reverse transcription PCR. The seriousness of this pandemic which has forced the world to shut down and cause immense loss of lives and the economy calls for an extremely fast detection method. Sensor-based detection methods have many advantages over traditional methods such as better sensitivity, robustness, easy availability, lower cost, and minimum requirement of sophisticated equipment [9]. Methods like loop-mediated isothermal amplification (LAMP) have a caliber of amplifying the viral DNA up to $1 \times 10^{39}$ times and identifying the virus. However, it may show inaccurate results and is not entirely reliable [10]. Incorporating the excellent properties of nanomaterials in viral detection devices can improve the efficacy by many folds. Silver nanoparticles (AgNPs) have been used to develop a paper-based colorimetric detecting device for the MERS coronavirus [11]. Similarly, an electrochemical immunesensor using gold nanoparticles (AuNPs) has been developed, which contains carbon electrodes to detect the human coronavirus [11]. The nanoparticles undergo a colorimetric change on interaction with the virus by (1) showing peroxidase-like activity $[12,13],(2)$ aggregation of the nanomaterial or (3) destabilization of the nanomaterial structure[14]. Researchers have exploited these characteristic features of the nanomaterials for HIV-AIDS detection [15]. Presently, surface-modified magnetic nanoparticles are being used to isolate the RNA of Coronavirus, which is the prime step for its identification [16]. Recent research suggests using electrodeposited AuNPs to make a labelfree electrochemical transduction scheme for the Coronavirus RNA [17]. These newly developed point-of-care detection methods are rapid, sensitive, and cost-effective. The current research direction is to make these sensors user-friendly to avoid the requirement of highly skilled lab technicians. Testing the presence of antibodies in the blood against Coronavirus is another effective and inexpensive detection method that can detect the virus within minutes even if the individual is asymptomatic [18]. CRISPR-based sensors are a rapid biotechnological approach for diagnosing the virus with minimal equipment requirements and quick results [19]. Efforts are being made in all the disciplines e.g., biotechnology, chemistry, and instrumentation for the development of the quickest possible recognition technique. This review aims to summarise the advances in nanomaterial-based sensors for the detection of novel Coronavirus and to discuss the most rapid, economical, and easy-to-use sensor.

\section{COVID-19}

Coronaviruses have been the cause for two large-scale epidemics in the past, SARS-CoV and MERS in 2002 and 2012 respectively. Coronaviruses infectious to humans are $\mathrm{HCoV}_{229} \mathrm{E}$ and $\mathrm{NL}_{63}$ (alphacoronavirus) and $\mathrm{HCoV} \mathrm{OC} 43$, $\mathrm{HKU}_{1}$, SARS-CoV, and MERS-CoV (betacoronavirus) [20].

In 2019, the third outbreak of the coronavirus occurred and showed symptoms similar to pneumonia [21]. The virus was identified when the throat swab and lower respiratory tract samples were collected and tested by RT PCR technique [22]. Later it was found that the cause of infection was "Severe Acute Respiratory Syndrome Coronavirus 2" (SARS CoV-2). This virus belongs to the coronaviridae family of viruses and comes under the subfamily coronavirinae and genus Betacoronavirus [23-26]. SARS CoV-2 is a spherical virus with a diameter of $60-100 \mathrm{~nm}$ and can show pleomorphism $[4,25]$. The virus has 4 structural proteins viz. the spike protein (S), envelope (E), membrane (M), and nucleocapsid (N) [25] Fig. 1 along with non-structural proteins, such as $\operatorname{RdRp}(\mathrm{nsp} 12)$, and proteases, such as nsp3 and nsp5 [27].

Out of all structural proteins, spike protein (S) is responsible for attaching the virus to the host cell membrane [27]. The spike protein comprises 2 subunits S1 and S2. Under the lipid layer nucleocapsid protein $(\mathrm{N})$ is present which is crucial for the replication of the virus [28]. In humans, SARS CoV-2 virus targeting the ACE2 receptors present mainly on the lungs, kidneys, heart, and intestines [29].

\section{Conventional Detection Methods}

Currently, the molecular assay of choice for coronavirus detection remains qRT-PCR, along with antibody-based techniques as supplementary tools [30]. Although a lot more advanced detection kits are being developed, PCR-based

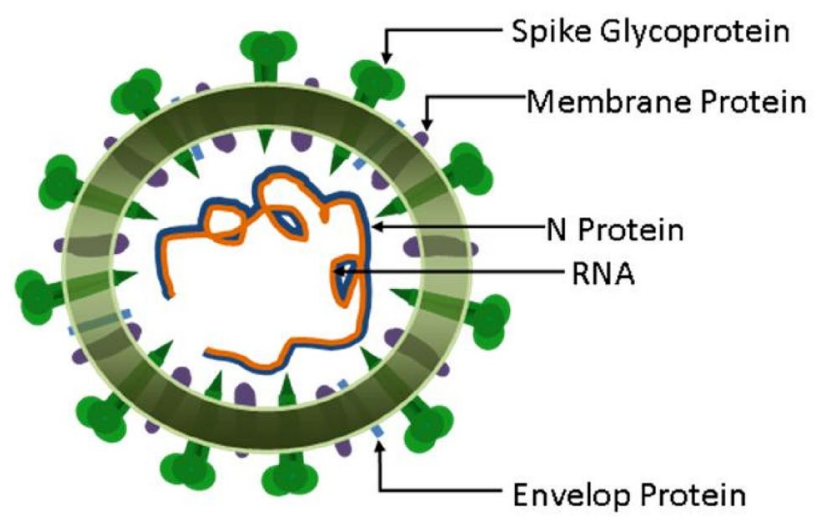

Fig. 1 Schematic representation of cross section of SARS-CoV-2 
detection is still the most widely used technique because of its high reliability and sensitivity. It is considered as the gold standard for virus detection [31]. These methods require highly skilled lab technicians, class II and class III bio-safety levels [32].

\subsection{Immunodetection}

In the presence of SARS-CoV-2 in the body, the immune response is triggered and produces IgM or IgG antibodies. Immunodetection assays identifying these SARS CoV-2 specific antibodies in the blood are utilized for detection of the virus. This type of detection can be immensely helpful in recognizing asymptomatic individuals [30]. There is copious production of highly immunogenic $\mathrm{S}$ and $\mathrm{N}$ proteins during the infection. These proteins can act as antigens and potentially help in detecting SARS-CoV-2 serologically [32].

However, it is very well known that IgM responses may be non-specific sometimes and show less sensitivity in the early stages of infection [30]. Although compared to PCRbased assay, this technique does not depend on viral genome amplification, and requires much less time and equipment [32].

\subsection{PCR-Based Assay}

Real-time Reverse transcription PCR and Droplet-digital PCR are the molecular assays currently used for SARS CoV-2 detection [33]. These nucleic acid amplification tests
(NAAT) work on the principle of amplifying the genome of the virus billions of times with the help of primers and polymerases. Forward and reverse primers attach to the target sequence while the polymerase attaches nucleobases complementary to the target DNA strand [34]. The technique of qRT-PCR includes the use of either a TaqMan probe or an intercalating dye, which gives increasing fluorescence in positive results. If the viral RNA is present in the sample, the probe breaks down with the activity of DNA polymerase and the fluorescent end and the quencher end no longer remain in close vicinity. As more copies of the target sequence are produced, more probes cleave and break down, increasing the fluorescence [35]. As soon as the Chinese Centre For Disease Control And Prevention released the complete genome sequence of the novel virus, the primers identical to a specific genome sequence were designed in the laboratories [36, 37]. Since the virus is mutating and altering its genome sequence, it is necessary to develop a multiplex PCR with increased sensitivity [38]. It also helps to reduce the chances of contamination [30].

However, in extreme conditions such as the $\mathrm{nCoV}$ outbreak, a better point-of-care diagnosis is needed. The PCRbased assay involves cautious sample collection, highly skilled lab technicians, and costly reagents. Placing the swab in the wrong anatomic site during sample collection and not storing it correctly can also lead to inaccuracy. Mutations in genetic sequences of the virus are one of the biggest hurdles in conducting successful PCR assays as the primer sequence fails to bind [31]. Table 1 lists the conventional techniques for the detection of viruses.

Table 1 List of conventional techniques for detection of viruses

\begin{tabular}{|c|c|c|c|c|}
\hline Virus & Technique for detection & Principle & Time taken & References \\
\hline \multirow[t]{2}{*}{ SARS-CoV-2 } & qRT-PCR & $\begin{array}{l}\text { Amplification of target sequence and real-time detection by spectroscopy } \\
\text { of fluorescence }\end{array}$ & $6-8 \mathrm{~h}$ & {$[30]$} \\
\hline & Rapid antigen testing & Agglutination after antigen-antibody interaction & $15-20 \mathrm{~min}$ & [39] \\
\hline MERS-CoV & RT-PCR & $\begin{array}{l}\text { Amplification of target sequence and real-time detection by spectroscopy } \\
\text { of fluorescence }\end{array}$ & $\sim 6 \mathrm{~h}$ & [40] \\
\hline \multirow[t]{2}{*}{ Zika virus } & PCR & $\begin{array}{l}\text { Amplification of viral genome } \\
\text { Binding of the conjugate to IgM }\end{array}$ & $\sim 4-6 \mathrm{~h}$ & {$[41,42]$} \\
\hline & ELISA & Enzyme-linked to an antibody or antigen acts as a marker for detection & $2.5-4 \mathrm{~h}$ & \\
\hline \multirow[t]{2}{*}{ Hepatitis B } & Rapid diagnostic testing & $\begin{array}{l}\text { The capture of dye-linked antibodies produces a visible band on the } \\
\text { nitrocellulose membrane }\end{array}$ & $30 \mathrm{~min}$ & [43] \\
\hline & HBsAg surface antigen test & The blood sample is tested for HBsAg antigen & $\sim$ & \\
\hline \multirow[t]{2}{*}{ Influenza } & Virus culture & $\begin{array}{l}\text { Cell cultured are monitored for morphological changes. Confirmed by the } \\
\text { presence of immunofluorescent monoclonal antibody against influenza } \\
\text { A or B }\end{array}$ & $2-14$ days & [44] \\
\hline & Fluorescent antibody test & $\begin{array}{l}\text { In presence of the target antigen, the fluorescent tag conjugated antibody } \\
\text { generates a protein tag }\end{array}$ & $2-4 \mathrm{~h}$ & \\
\hline \multirow[t]{2}{*}{ Ebola } & Cell culture & $\begin{array}{l}\text { The virus is isolated in cell culture and visualized by electron or immuno- } \\
\text { fluorescence microscopy }\end{array}$ & $1-5$ days & {$[45,46]$} \\
\hline & IgM and IgG ELISA & $\begin{array}{l}\text { Ebola antibodies are captured by the antigens placed on the microtiter } \\
\text { plate. Horseradish peroxidase detects these complexes }\end{array}$ & $2.5-4 \mathrm{~h}$ & \\
\hline
\end{tabular}




\section{Sensor-Based Detection}

The overwhelming need for mass testing of COVID-19 has inculcated the requirement of rapid, reproducible, and inexpensive sensors [47]. Such sensors are designed based on their affinity for the relevant target [48]. Biosensors are conjugated with aptamers, peptide arrays, polymers, and other attachments to recognize, read and produce a detectable output signal to identify the virus, ideally with naked eyes [49]. The targets for biosensors to detect Coronavirus can be its RNA or antigens and antibodies produced by the host $[47,48]$. In the SARS-CoV epidemic in 2002, RNA aptamers were coated with nanoparticles to detect the nucleocapsid protein of the virus. The process was sensitive, rapid, and was done on a chip [50]. The current outbreak has also led to the development of such nanomaterial-based sensors to enhance rapid antigen testing. Nanoparticles have a high surface-to-volume ratio, exploitable surface plasmon resonance, unique optical, chemical, and electrical properties [51]. Due to these diverse properties, nanoparticles are capable of making a wide variety of sensors, including electrochemical, optical, colorimetric, voltammetric, etc. [48]. As the host produces a large number of $\mathrm{IgM}$ and $\mathrm{IgG}$ antibodies against the virus, using them to diagnose the virus can provide an excellent point-ofcare detection tool. Since the blood samples are collected, the individual conducting the tests is not exposed to the infected nose/oral swabs [52].

A lateral flow assay was created to detect anti-SARSCoV-2 IgG antibodies using lanthanide-doped nanoparticles [53]. RNA of the virus was extracted and RT-PCR was used to give a full-length nucleocapsid protein as the PCR product. It was then cloned in pMD-19 T (vector) which was further cloned in a linear vector. The $\mathrm{N}$ protein was expressed in E. Coli to give the maximum expression of the protein. Lanthanide-doped NP was made by mini-emulsion polymerization [53, 54]. Mouse anti-human IgG and rabbit anti-human IgG antibodies were conjugated with these NPs, and the strips were fabricated with them. Here, Fig. 2 represents the schematic representation of the strip developed and used for testing. The strip consisted of a sample pad (with a sample well), conjugate pad, absorbent, nitrocellulose membrane, test line, and a control line [53]. This assembly was then enclosed in a plastic shell. As the serum sample was loaded into the well, the liquid moved towards the absorbent pad. During this period, the lanthanide NPs were captured in control and test lines. Fluorescence was detected after $10 \mathrm{~min}$ in a fluorescence detector at a wavelength of 365 and $615 \mathrm{~nm}$. As the NPs are excited, they emit fluorescence on the membrane [53].

Similarly, another AuNP-LF assay was created to detect the presence of IgM antibodies against the novel virus in the blood [52]. The process took advantage of the highly specific immune responses and excellent properties of AuNPs. The Coronavirus nucleoprotein was coated with a membrane to capture the sample, and anti-human IgM was coupled with AuNPs to act as a detector. The conjugate pad consisted of the AuNPs (anti-human IgM), and the nitrocellulose membrane was dispersed with SARS-CoV-2 NP [52].

The AuNPs were synthesized using $\mathrm{HAuCl}_{4}$ and trisodium citrate. Then the SARS-CoV-2 NP was expressed by amplifying the $\mathrm{N}$ gene by RT-PCR and cloning it into an expression vector. These AuNP lateral flow strips can give the results in 15 min with just $10-20 \mu \mathrm{L}$ of the sample. The AuNPs provide biocompatibility, and the test can be conducted without any sophisticated types of equipment [52].

Reverse-transcription loop amplified isothermal amplification has been used to detect various RNA-based viruses such as MERS coronavirus [55]. This LAMP technique has been modified and improved with the aid of nanoparticles to
Fig. 2 Working principle of AuNPs-LF assay. a Arrangement of the chip; $\mathbf{b}$ antibody binding to nanoparticles conjugated antigen gives a positive result; $\mathbf{c}$ no antibody binding to nanoparticles conjugated antigen gives a negative result a AuNPs-LF Strip(Structure)

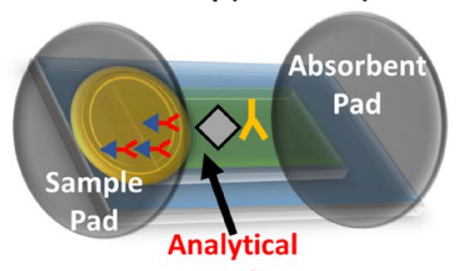

Pad
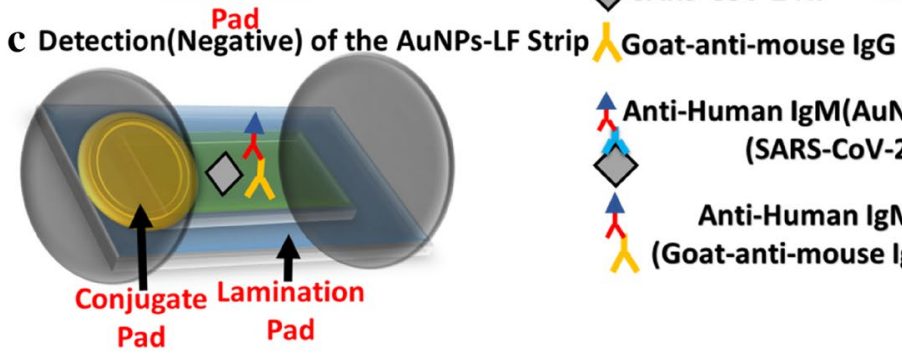

b Detection(Positive) of the AuNPs-LF Strip

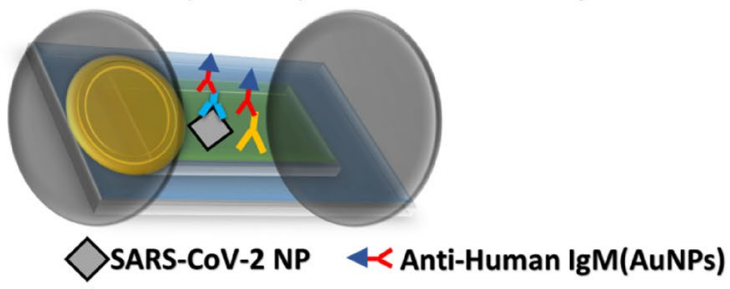

Anti-Human IgM(AuNPs) - (SARS-CoV-2 IgM) (SARS-CoV-2 NP) compound

Anti-Human IgM(AuNPs) (Goat-anti-mouse IgG) compound 
detect the SARS-CoV in this pandemic [56]. The approach combined the effectiveness of nanoparticle-based sensors with the rapidness of RT-LAMP. LAMP process eliminates the need for a thermal cycler and amplifies the target area of the genome more rapidly with very high specificity since 6 to 8 target sequences are recognized. To recognize SARS$\mathrm{CoV}-2$, F1ab and np regions were amplified from the virus genome. The rabbit-anti-fluorescein antibody and sheep antidigoxigenin antibodies were fabricated on the nitrocellulose membrane of the sensor. The nanoparticles were coated with streptavidin dye to recognize two target amplicons and a chromatography control [56].

In all these methods mentioned above, the test line determines the result and the control line ensures the proper working of the detector. Attaching the antibodies to the NPs conjugated with SARS-CoV protein triggers a response that gives rise to fluorescence, which is because of the surfaceenhanced Raman scattering effect of the NPs. While the antihuman IgG and IgM also attaching with the antibodies in the serum to ensure their presence in the sample [57].

Nanomaterials possess unique physical, chemical, electrical and optical properties that bulk materials fail to deliver [58]. They have a high potential for application in biosensors because they work on the same scale as biological processes and can be easily functionalized with substrates of interest. Their real-time results and inexpensive approach make them one of the most excellent materials to make biosensors in such outbreaks [59].

\subsection{Electrochemical Biosensors}

An electrochemical sensor recognizes the biological action of bio-analytes such as antibodies and enzymes specific to a particular pathogen and converts these changes into measurable signals in the form of current, impedance, or potential [60]. It consists of a chemical layer for recognition and an electrochemical transducer that transfers the signal from the recognition site to the electrical detecting domain [60]. These sensors can either have a liquid electrolyte or a solid electrolyte and can function amperometrically or potentiometrically [61]. Electrochemical sensors have previously been used to detect viruses such as Influenza [61]. Due to the vast and rapid outspread of COVID-19, a sensor with the ability to be used in places not equipped with sophisticated equipment is required and electrochemical sensors have the highest potential to achieve this objective.

In recent study, a label-free electrochemical approach was proposed to detect the COVID-19 genome using AuNPs as the transducers [17]. The concern is to miniaturize the device model and make it portable and economical. AuNPs electrodeposited on Titanium electrodes were used for making the working electrode, and Pt was opted for reference and counter electrodes. The AuNPs provide stability and protection against harsh chemicals to the electrode. A complementary probe for coronavirus RNA or cDNA was designed with a thiol end where the $\mathrm{Au}$ nanoparticles were immobilized on the titanium substrate as shown in Fig. 3a. Through Au-thiol self-assembly, the modified probe was attached to the NPs in the sensing domain. After using blocking agents, the surface was ready for diagnosis, as shown in Fig. 3b, when the coronavirus genome binds to the probe by DNA hybridization, the surface charge is altered significantly and reaction kinetics are changed. These physicochemical changes can be measured by different electrochemical approaches [17].

This type of device is still being developed. Previously such sensors have proved to be successful in virus detection and have a promising future in the $\mathrm{n}-\mathrm{CoV}$ diagnosis too. Portability and the ability to connect with everyday electronic devices such as smartphones and laptops is one of the most significant advantages of electrochemical sensor-based devices. With worldwide efforts, it is hoped that
Fig. 3 Diagramatic representation of DNA detection. a Immobilization of AuNPs on Ti substrate; b thiol self-assembly and hybridization complex $\mathbf{a}$

b

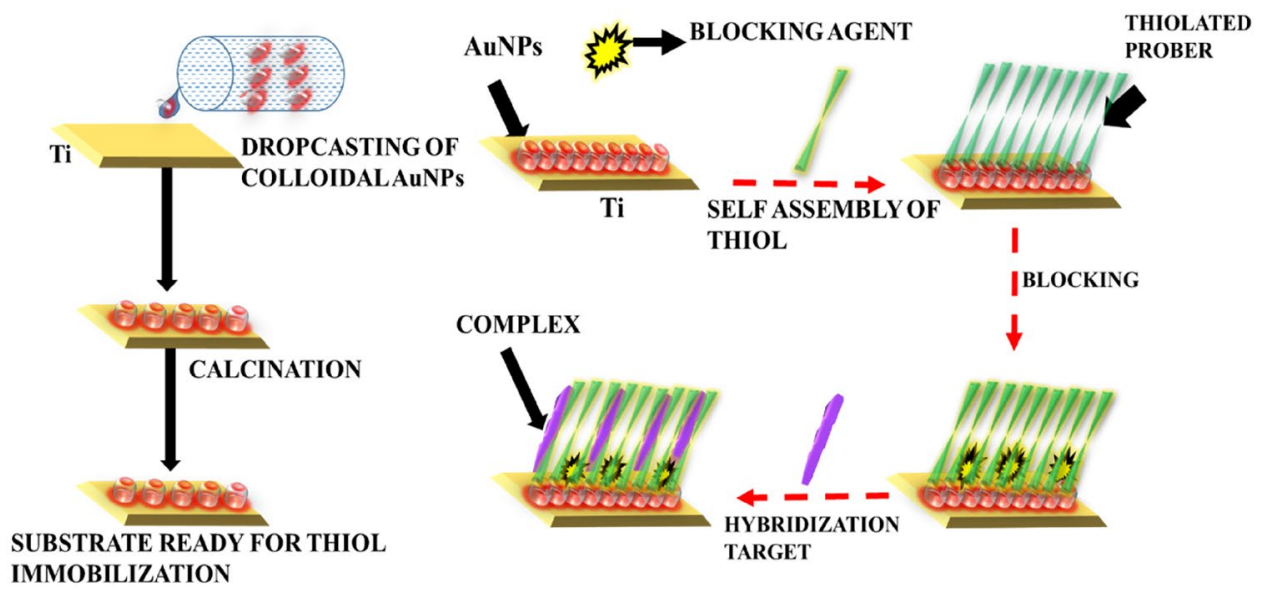


these sensors will be fully functional in a few months and will entirely change the cumbersome detection processes. In a recent publication, an AuNP based sensor was made for detecting SARS-CoV-2 from exhaled breath [62]. The study was based on a recent finding which suggested that SARS-CoV-2 has viral agents which create a microenvironment emitting volatile organic compounds (VOCs) [63]. The AuNPs in the sensor are conjugated with organic ligands, creating a sensing layer with the NPs acting as the conductive material along with sites provided specifically for the VOCs to get adsorbed by the organic layer. When the individual, to be tested, exhales on the sensing area of the device, the organic ligands and functional groups conjugated with the AuNP react with the VOCs resulting in shrinkage or swelling of the AuNP sensing layer (Fig. 4). This volume change fluctuates the electric resistance which can be measured and displayed digitally. The usage of the device on multiple individuals requires repeated cleaning with alcohol and flushing the sensor with air after every use. In addition, the presence of humidity in the breath can reduce the sensitivity of the sensor. Therefore, the device can be seen as a preliminary test for COVID-19 rather than an alternative for the pre-existing and established tests. However, the flexibility of the sensor is extraordinary and comparable to the widely used breath alcohol analyzer.

\subsubsection{Voltammetric Biosensors}

Voltammetric sensors are a part of electrochemical sensors that detect the analyte by measuring the current concerning the different potential [60]. Any standard voltammetric sensor has an electrochemical sensing device, a detecting instrument, and an electrolyte. The detecting domain includes a working electrode that interacts with the analyte, a reference electrode with a known potential, and a counter electrode [64]. A voltammetric sensor can either be stripped (adsorptive stripping voltammetry and anodic stripping voltammetry) or nonstripped (cyclic and linear sweep voltammetry)
[65]. Stripping voltammetry provides more sensitivity as the analyte is rapidly adsorbed on the electrode surface without any requirement of electrolysis [66]. Graphene possess a unique honeycomb lattice structure with $\mathrm{sp}^{2}$ bonded carbon atoms with high electrical conductivity, a tunable bandgap, and optical properties, making it ideal for Field Effect Transistor (FET) sensors [67]. The graphene-based biosensors show the best performance when they are functionalized via chemical route. The heterogeneous electron transfer eventuating at the edges and defects of graphene sheets along with the remarkable surface area make them significant in sensing technologies [68]. Graphene oxide (GO) shows similar electrochemical and thermal properties as graphene and can be made into nanosheets. GO can be immensely helpful in developing biosensors due to the readily available functional groups which are helpful in the attachment of several types of biomolecules [69]. In a recent study, A graphene-based biosensor fabricated with SARS-CoV-2 spike antibodies was developed [70]. The graphene layer was passivated with a photoresist and chemically functionalized with 1-pyrenebutyric acid N-hydroxysuccinimide ester (PBASE). The total sensing area was of dimension $100 \times 100 \mu^{2}$. After the successful binding of PBASE with the graphene layer, two different peaks were observed after X-ray photoelectron spectroscopy as a result of the relative resonance of $\mathrm{sp}^{3}$ bonding. The spike antibody of the virus was preferred for detection due to the high immunogenicity of the spike protein. Phosphate buffer saline was added as an electrolyte to create an aqueous gated biosensor with the ability to detect SARS-CoV-2. With the help of the Current-Voltage graph, variation in current $\left(\left(\Delta I / I_{0}\right)\left(I-I_{0}\right) / I_{0}\right.$, where $I$ refers to the detected real-time current and $I_{0}$ refers to the initial current) is measured. After the attachment of coronavirus spike protein to the detecting surface change in current was observed (Fig. 5). The process could also give precise results in virus samples from the transport medium of a nasopharyngeal swab and the limit of detection was $1 \mathrm{fg} / \mathrm{mL}$.
Fig. 4 AuNPs based sensor for breath analysis of SARS-CoV-2

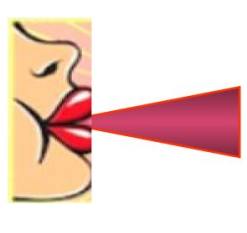

Breath of Person

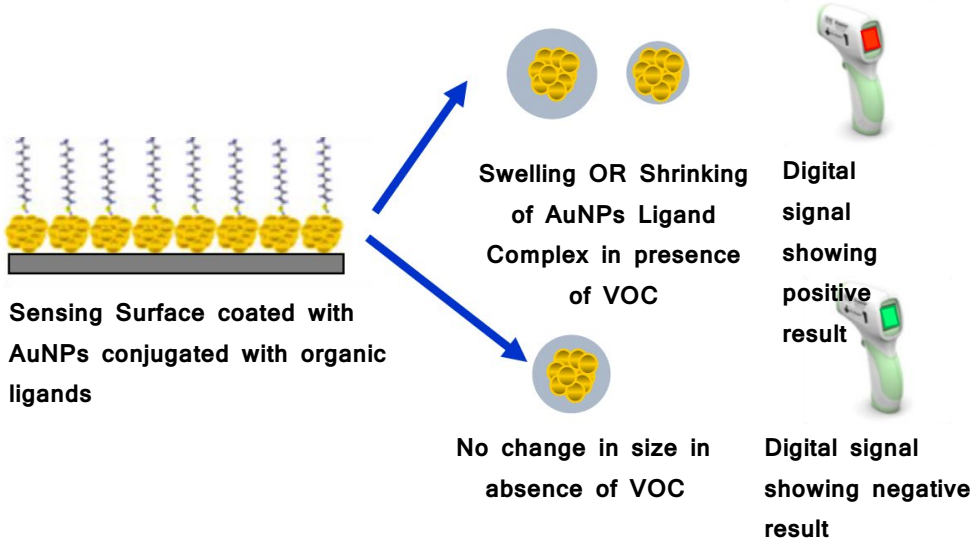


$\mathbf{a}$

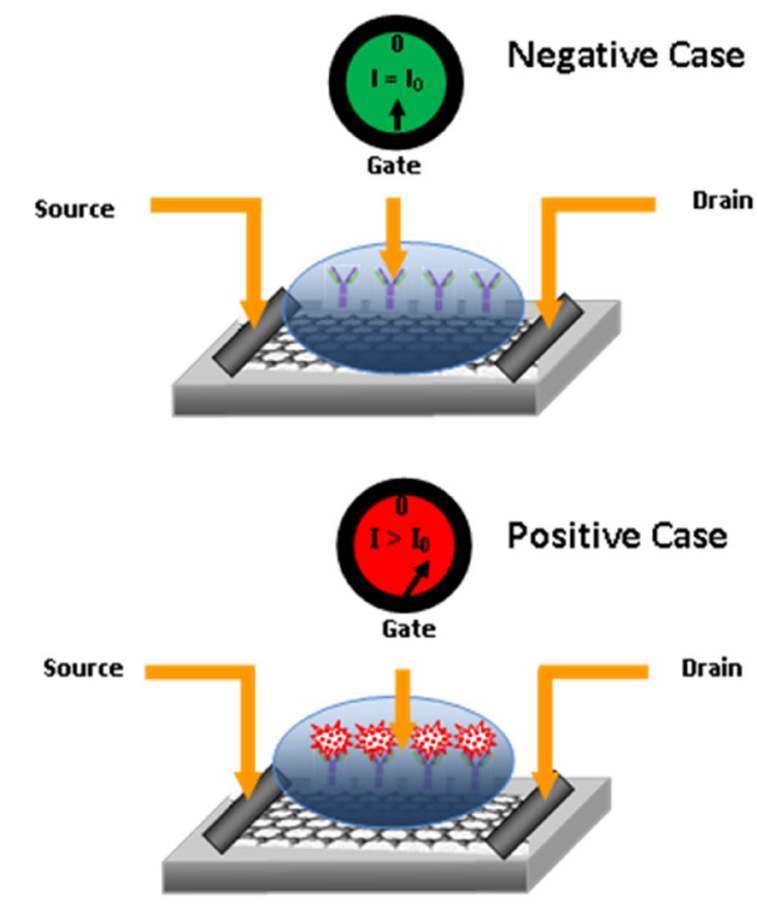

Fig. 5 Graphene-based FET sensor. a No change in gate current for normal sample; $\mathbf{b}$ increase in gate current with SARS-CoV-2 positive sample

The Graphene-based sensor i.e. mentioned in Fig. 5 seems quite promising, however, the need for purified and high quality graphene is difficult to be obtained at kilogram or industrial scale for making a large number of such devices. Since the purity of graphene is one of the major concerns needed for these devices to have higher sensitivity, producing graphene with consistent quality (as required in this sensor) is still a challenge and any error in the making process can lead to an inaccurate biosensor.

In the previous outbreak of coronavirus MERS, a voltammetric immunosensor was developed using carbon electrodes modified with AuNPs [71]. An indirect competition between the free virus in the sample and MERS coronavirus spike protein was used to design the immunoassay and the change in the current peak was observed by the square wave voltammetry technique. Eight electrodes were designed with AuNPs electrodeposited on them and these electrodes were then coated with HCoV/MERS CoV antigens. Ferro/ferricyanide redox couple was incorporated in the sensor. BSA solution inhibited the inactive aldehyde molecules to free the Au electrode surface [71]. When the sample containing antibodies against the MERS coronavirus interacted with the modified immunoassay electrodes, binding of the antigens attached on the electrode surface and the antibodies in the sample occurred. As the antibodies are of considerable size $(\sim 150 \mathrm{kDa})$, a large area of the electrode was covered by it. This led to a decrease in the peak current of the redox couple, which was detected by square wave voltammetry [71]. The complete test took about 20 min to detect viral antibodies.

Since the SARS-CoV-2 belongs to the same genera as MERS-CoV, the eight electrodes designed for this assay can be modified and enhanced for COVID-19 detection. Also, to test a large number of samples in a single reaction, the number of electrodes can be increased. This type of approach promises portable, cheap and rapid testing procedures for the novel coronavirus [71].

\subsubsection{Impedimetric Biosensors}

Impedimetric sensors are self-contained devices that give a measurable change in capacitance or a shift in impedance after the capture of the analyte on the electrode surface [72]. $\mathrm{AC}$ current is usually used to note the changes in capacitance and the drifting of this AC current from the network of capacitors and inductors gives a complex resistance which is called the impedance [73]. Immunosensors and aptasensors are the most commonly used electrochemical- impedimetric sensors. The impedimetric immunosensors can either be capacitive or Faradic based on the type of signal measured. Capacitive sensors do not require a redox probe and the formation of antibody-antigen complexes decreases the capacitance while faradic sensors employ a redox probe as the electrode is partially insulated and the resistance is transferred to a lower frequency to measure the detection [74].

An impedimetric immunosensor ensures label-free detection of viruses through antibody-antigen interactions, and the incorporation of metallic nanoparticles in these sensors provides extraordinary conductivity and stability [73]. When the Zika virus outbreak occurred in 2015, a label-free impedimetric immunosensor was designed with an oxidized glassy electrode enhanced with AuNP-SiPy. The sensor worked by detecting the antibodies against the virus in the serum sample by $\mathrm{Au}-\mathrm{S}$ covalent bond formation [75]. Bode and Nyquist representations are generally used to analyze and evaluate the electrochemical impedance spectroscopy in graphical formats [76]. Receptors can be immobilized by cross-linking, entrapment in gels/films, or adsorption, giving the sensor versatility for detection processes [72]. SARS$\mathrm{CoV}-2$ diagnosis can be made much easier by incorporating these impedance-based biosensors in the testing facilities as they exhibit the ability to be integrated with multi-array diagnostic tools ensuring testing of multiple samples in a single test. By taking care of the reproducibility of these point-of-care detection kits, they can become a potential replacement for the current conventional assays.

Carbon nanotubes are considered as elite nanomaterials for fabrication in biosensors. Being carbon-based materials, they allow direct electron transfer to the assembled bioreceptors such as antibodies and antigens [77]. They have 
one of the simplest chemical compositions and can occur as multi-walled or single-walled nanotubes. The curvature of the tube, presence of edge-plane-like sites, and defects give nanotubes a compelling electro activity [78]. Bare carbon nanotubes have high cytotoxicity. Ge et al. reported that with the help of binding proteins, the high cytotoxicity of bare carbon nanotubes can be reduced [79]. The bio-receptors will help recognize the element of the tubes acting as transducers to detect the stimulation and convert it into a detectable output signal [80]. In the past, multiwall carbon nanotubes (MWCNT) were used to develop a DNA-based sensor to detect the Influenza virus [81]. DNA probe was fabricated on the MWCNT with the aid of amine and phosphate covalent bonding. The nanotube was functionalized using boiling nitric acid. When the probe and target binding took place, the conductance changed on the CNT surface giving a changed output signal. Similar sensors can be developed for the coronavirus. As of now, the virus has been widely studied and we have the information about its structure, interaction with human cells, and replication process, making the use of CNTs can provide instantaneous biosensors. According to a recent study, incorporating MWCNT with dendrite-modified electrode can prove to be an excellent surface for sensing [82].

However, maintaining this level of sophistication while producing these devices on a large scale for use among huge populations is still uncertain. Therefore, along with these complex working mechanisms, a reliable production method and machinery are highly required for the quick development of biosensors.

\subsection{Colorimetric Sensors}

Colorimetric sensors are detectors that give a noticeable change in color in the visible range (380-700 $\mathrm{nm}$ ) when in contact with any analyte [83, 84]. They are associated with the class of optical sensors [85]. Just like every other type of sensor, colorimetric sensors also consist of a receptor, transducer, and a detecting domain, but the layout and choice of the material depend on the type of external stimuli interacting with it [85]. The optical properties of a nanoparticle are linked with its surface Plasmon resonance (SPR). When there is any optical polarization, the electric field of the NP is enhanced, resulting in light scattering and absorption at a specific frequency of SPR [86]. This adjustable surface Plasmon resonance acquired by the nanoparticles helps them to change color used in the functioning of nanobiosensors [84, 87]. For example, when AuNPs of $20 \mathrm{~nm}$ are suspended in an aqueous solution, they give a typical red wine color $(\sim 530 \mathrm{~nm})$ due to the SPR peak in the absorption spectrum. But when these nanoparticles agglomerate (due to any interaction), the color changes owing to the change in the plasmonic resonance [88]. Similarly, in the presence of the viral
DNA, a keen red shift is detected in the silver nanoparticles when the agglomeration changes the color from yellow to orange [10].

Nanoparticles consist of an equal number of positive ions and negatively charged electrons that overlap in the neutral state. Nevertheless, when electromagnetic radiation is incident on it, the electrons tend to move away from their equilibrium position leading to an increase in their density in a particular region. In such a situation, they repel each other and oscillate back to their equilibrium positions with some kinetic energy. As the electrons on the surface are affected the most, their collective oscillations give an intense peak in the visible light range [89]. In a recent publication, nakedeye detection of SARS-CoV-2 has been conducted with the aid of Au plasmonic nanoparticles [90]. Plasmonic nanoparticles work as a detection tool when the frequency of the photon incident on it matches the frequency of the excited electrons of the nanoparticles [91]. This change in SPR peak causes a color change that does not require any detection machinery, and thus, the results can be interpreted even by a layman. For the working of this sensor, four ASO (antisense oligonucleotide) sequences covering four specific regions of the $\mathrm{N}$ gene were designed. Scientists have figured out great scope of development of biosensors targeting the $\mathrm{N}$ gene because of its limit of detection of 8.3 copies per reaction while RdRp and $E$ gene have 3.6 and 3.9 copies per reaction, respectively. These ASOs were capped on plasmonic NPs after thiolating them at one end. Since these ASO capped NPs showed agglomeration only in the presence of the SARS-CoV-2 RNA sequence, the evident change in color with the specific binding could show positive results. ASO1 and ASO3 were thiolated at their 5' end while ASO2 and ASO4 were thiolated at their 3' end [90].

The hydrodynamic diameter of the NPs was significantly increased when SARS-CoV-2 RNA was attached to it, which amplified its tendency of aggregation. A red shift of $40 \mathrm{~nm}$ was observed with an increase in absorbance at the wavelength of $660 \mathrm{~nm}$ [89]. The change in the SPR peak changed the color of the solution from violet to dark blue. This change involves a minor red shift of $40 \mathrm{~nm}$, thus to make the results more prominent, RNase $\mathrm{H}$ (non-sequence specific endonuclease) was added to the solution. RNase is known to exhibit hydrolyzing abilities for RNA/DNA hybrids, and thus cleaves the Au-ASO mix and SARS-CoV-2 bonds forming noticeable precipitate facilitating immediate visual detection. Since the process uses four ASOs targeting two regions of the $\mathrm{N}$ gene, the accuracy and convenience increases because the virus has shown signs of mutating [92]. Therefore, even if one target area is mutated, the second one can be detected by this process.

The large surface area provided by the nanoparticles can be beneficial for SARS-CoV-2 biosensors. Moreover, the development of these intricate biosensors in laboratories is 
very different from an industrial point of view. Therefore, mass production is also one of the factors to be considered among rapidness and high specificity.

Table 2 summarises the advantages offered by a particular type of sensor along with their limitations.

\subsection{Fluorescent Sensors}

One of the most widely studied materials in nanotechnology is quantum dots. They are semiconductor particles or crystals with electrons and valance bond holes confined in the quantum realm in all three spatial dimensions [93]. Due to their unique optical properties, quantum dots have earned a place in sensing technologies as fluorescent agents. They are photo-chemically stable with high fluorescence quantum yield and broad excitation spectra and have exceptional emissive properties. These resilient properties make them suitable for use in a variety of biosensors such as immunoassays, nucleic acid detection, and Fluorescence Resonance Energy Transfer (FRET) sensors [93, 94]. In a recent publication, pseudo-virions were created by linking the SARSCoV-2 spike receptor-binding domain with fluorescent quantum dots. The ACE-2 receptors were linked with AuNP to study their interactions with the virus. This flexible imaging probe proved to be very successful in monitoring the binding and cellular internalization. The energy transfer followed by this reaction could be used to monitor the binding reaction and can be used for a potential biosensor [95].

Among all nanomaterials, nanorods are known for showing prodigious surface plasmon resonance exploitable for use in biosensors [96]. The use of gold and silver nanorods has attracted attention owing to their atypical optical properties. Previously, DNA-based fluorescent sensors have been developed to detect the Hepatitis B virus by Au nanorods. The Au nanorod surface was modified by wrapping it with CTAB (cetyltrimethylammonium bromide) to give a positive charge. When the fluorescein tagged, ssDNA added to the reaction mixture has a negative charge, so it was readily adsorbed on the Au nanorod surface to form a ternary complex (FAM-ssDNA-CTAB-AuNRs). This binding led to a decrease in the fluorescence emitted by the nanorod due to fluorescence resonance energy transfer [97].

\subsection{Microarray-Based Sensors}

DNA microarrays are considered the forefathers of DNAbased sensors. Usually, these arrays are used to study gene expressions. Microarray sensors recognize the molecular event of DNA hybridization on their sensing surface and convert it into a detectable signal, which is usually fluorescence [98]. A microarray is usually a glass or silica slide with thousands of spots on it. These spots have known segments of DNA and probes that can pair with their complementary DNA. The mRNAs are isolated from the unknown sample and are reverse transcribed into cDNAs which are then released on the microarray chip. If the binding takes place, the scanner detects it at the end of the process. These arrays function with high specificity because of the precise process of DNA hybridization [99]. The microarray-based sensors have been experimented in the previous SARS outbreak and can be developed for SARS-CoV-2 too [100]. By incorporating a suitable probe and producing reverse transcripted cDNAs, this approach can be employed in the diagnosis of this novel virus. The complete genome of the coronavirus was studied and a 60 -mer oligonucleotide sequence was designed, which was immobilized on the microarray chip along with probes [101]. The samples from infected individuals were collected and the RNA of the virus was reverse-transcripted into cDNAs. After the conduction of hybridization, negative samples did not give any signal and positive samples were detected in the scanner. A universal microarray with six SNPs as targets was designed to combat the hindrance produced by the coronavirus mutations in the diagnosis [102]. This included the fusion of RT-PCR with a ligase detection reaction.

An immune response-based microarray has been developed to detect SARS-CoV-2 [103]. The microarray panel consisted of coronavirus antigen, including spike protein domains and nucleocapsid protein genes. In their study, researchers added SARS-CoV, MERS-CoV, and common cold coronaviruses along with the COVID-19 samples. The

Table 2 Merits and challenges of various sensors

\begin{tabular}{|c|c|c|c|}
\hline Type of sensors & Merits & Challenges & Reference \\
\hline Colorimetric & $\begin{array}{l}\text { Naked eye detection } \\
\text { No sophisticated equipment or utilities are required }\end{array}$ & $\begin{array}{l}\text { Use and throw devices } \\
\text { Prone to interference giving inaccurate results }\end{array}$ & [83-85] \\
\hline Electrochemical based & $\begin{array}{l}\text { The sophisticated device directly gives digital readings } \\
\text { Repeatability is very good } \\
\text { Can be used multiple times }\end{array}$ & Unable to detect a low concentration of analyte & {$[17,70,73]$} \\
\hline Immune-based & $\begin{array}{l}\text { Mostly tested on blood samples } \\
\text { Able to identify asymptoatic patients }\end{array}$ & Unable to detect in the initial stage of infection & {$[30,32,52]$} \\
\hline
\end{tabular}


positive samples portrayed high reactivity to the SARsCoV-2 S and N proteins. Microarray-based sensors can provide manifest results for coronavirus identification and can be considered as a better alternative than PCR processes. It can detect thousands of DNA fragments in a single reaction. Along with better detection, it also provides a scope for vaccine development because of its capacity to study the entire gene sequence of the virus synchronously [100, 103].
Table 3 encapsulates the type of nanomaterial incorporated in the sensor along with their function and targets.

\section{Conclusions}

The coronavirus outbreak has highlighted the significance of biosensors as detection tools for rapid, sensitive, and selective sensing of this novel virus. This SARS-CoV-2

Table 3 List of various nanomaterials used in sensor devices

\begin{tabular}{|c|c|c|c|c|}
\hline Type of nanomaterial & Type of sensor & Working principle & Target & Reference \\
\hline $\begin{array}{l}\text { Lanthanide doped nanopar- } \\
\text { ticles }\end{array}$ & Colorimetric & $\begin{array}{l}\text { Works on basis of an immune } \\
\text { response, excitation of nano- } \\
\text { particles on binding with } \\
\text { antibodies }\end{array}$ & IgM antibodies & {$[53]$} \\
\hline Gold nanoparticles & Electro-chemical & $\begin{array}{l}\text { AuNPs work as electrodes } \\
\text { coronavirus genome binding } \\
\text { to thiolated probe (hybridi- } \\
\text { zation) gives a change in } \\
\text { surface charge }\end{array}$ & Genome/RNA & [17] \\
\hline Gold nanoparticles & Electro-chemical & $\begin{array}{l}\text { Shrinking or swelling of } \\
\text { AuNPs-Ligands sensing } \\
\text { layer after reaction with } \\
\text { volatile organic com- } \\
\text { pounds (VOC) generated in } \\
\text { COVID-19 patients }\end{array}$ & $\begin{array}{l}\text { VOC generated in COVID-19 } \\
\text { patients }\end{array}$ & {$[63]$} \\
\hline Gold nanoparticles & Voltammetric & $\begin{array}{l}\text { Decrease in peak current } \\
\text { detected by voltammetry } \\
\text { due to covering of electrode } \\
\text { by antibodies }\end{array}$ & MERS antibodies & [71] \\
\hline Gold nanoparticles & Colorimetric & $\begin{array}{l}\text { The red shift of } 40 \mathrm{~nm} \\
\text { observed after agglomera- } \\
\text { tion of ASO-capped AuNPs } \\
\text { on binding with SARS- } \\
\text { CoV-2 RNA }\end{array}$ & SARS-CoV-2 RNA & [91] \\
\hline Gold nanorods (AuNRs) & Colorimetric & $\begin{array}{l}\text { Decrease in fluorescence } \\
\text { intensity after binding of } \\
\text { hepatitis-B DNA to the } \\
\text { electrode surface }\end{array}$ & Hepatitis-B DNA & [97] \\
\hline Quantum Dots (QDs) & FRET & $\begin{array}{l}\text { Energy transfer after binding } \\
\text { of QDs linked SARS-CoV-2 } \\
\text { RBD and ACE-2 conjugated } \\
\text { with AuNPs }\end{array}$ & SARS-CoV-2 spike RBD & {$[95]$} \\
\hline $\begin{array}{l}\text { Magnetic nanoparticles ( } \mathrm{Zn} \\
\text { Ferrite) }\end{array}$ & Amplifier of genome & $\begin{array}{l}\text { Magnetic NPs-RNA } \\
\text { complex forms in lysis \& } \\
\text { binding buffer which can be } \\
\text { concentrated by sedimenta- } \\
\text { tion }\end{array}$ & SARS-CoV-2 RNA & [16] \\
\hline Carbon nanotubes (CNT) & $\begin{array}{l}\text { Electro-chemical/impedi- } \\
\text { metric }\end{array}$ & $\begin{array}{l}\text { After hybridization of influ- } \\
\text { enza virus DNA with elec- } \\
\text { trode surface coated with } \\
\text { CNT, variation is observed } \\
\text { in concentration dependant } \\
\text { charge }\end{array}$ & $\begin{array}{l}\text { DNA of influenza virus } \\
\text { (Type-A) }\end{array}$ & {$[81,82]$} \\
\hline Graphene & Voltammetric & $\begin{array}{l}\text { Attachment of antigen to } \\
\text { graphene-coated detecting } \\
\text { surface gives variation in } \\
\text { voltage }\end{array}$ & Spike protein/antigen & {$[70]$} \\
\hline
\end{tabular}


pandemic has affected millions of people globally and crumbled the economy. With advancements in sensor development and nanotechnology-enabled devices, we have presented some potential testing alternatives for the traditional process of RT-PCR. Even though the PCR-based approach is the gold standard, it demands time, sophistication, and expertise, which is not suitable in this case. Fast detection holds immense importance and can play a crucial role in containing the outspread. In this review, we have discussed sensors targeting the virus nucleocapsid protein, RNA, and antibodies produced by the host in response to the virus. Sensors confining the extraordinary properties of nanoparticles along with the specificity of antigen-antibody interactions like the AuNP lateral flow assay can provide an excellent detection kit that will be suitable for use by any individual. These sensors can identify the asymptomatic individuals with the collection of blood samples, also eliminating the exposure to infected nasopharyngeal swabs. The electrochemical method can provide a miniaturized device ensuring label-free detection of the virus. The sensor will be similar to a glucometer with the ability to digitally produce the results. Similar voltammetric and impedimetric biosensors enhanced with nanotechnology-enabled device integration and fabrication can give accurate and spontaneous results. These biosensors can test multiple samples with an increase in the number of electrodes. Biosensors delivering rapid naked-eye detection of the virus are under research based on the concept of colorimetry. Plasmonic AuNPs are being used along with four antisense oligonucleotides genes of the virus. Since the virus is mutating, this technique promises accurate detection even if a few regions are mutated. Colorimetric sensors give manifest results without the requirement of any additional device for studying the result. Another capable technique that can be integrated into the sensor can be microarrays. This intricate technique can test a large number of samples in much less time. With advancements in these sensor-based techniques, the novel coronavirus diagnosis will completely change in the coming time. As of now, blood and serum testing are being considered the most effective ones. The scope of development of a robust and rapid sensor for COVID-19 should be backed with successful commercialization and mass-scale production of these devices.

Acknowledgements The authors are thankful and highly obliged to the entire administration of AUUP, Noida, India, for bestowing their incessant assist for the above work.

\section{Declarations}

Conflict of interest The authors declare that they have no conflict of interests.

\section{References}

1. Wu YC, Chen CS, Chan YJ. The outbreak of COVID-19: an overview. J Chinese Med Assoc. 2020;83(3):217-20.

2. Sohrabi C, Alsafi Z, O’Neill N, Khan M, Kerwan A, Al-Jabir A, Iosifidis C, Agha R. Corrigendum to "World Health Organization declares Global Emergency: a review of the 2019 Novel Coronavirus(COVID-19).” Int J Surg. 2020;76:71-6.

3. Daga MK. From SARS-CoV to Coronavirus Disease 2019 (COVID-19)—a brief review. J Adv Res Med. 2020;6(3):1-9.

4. Mousavizadeh L, Ghasemi S. Genotype and phenotype of COVID-19: their roles in pathogenesis. J Microbiol Immunol Infect. 2021;54(2):159-63.

5. Singhal T. A review of Coronavirus Disease-2019 (COVID-19). Indian J Pediatr. 2020;87(4):281-6.

6. Mehta P, McAuley DF, Brown M, Sanchez E, Tattersall RS, Manson JJ. COVID-19: consider cytokine storm syndromes and immunosuppression. Lancet. 2020;395(10229):1033-4.

7. Vankadari N, Wilce JA. Emerging WuHan (COVID-19) coronavirus: glycan shield and structure prediction of spike glycoprotein and its interaction with human CD26. Emerg Microbes Infect. 2020;9(1):601-4.

8. Peeples L. Avoiding pitfalls in the pursuit of a COVID-19 vaccine. Proc Natl Acad Sci USA. 2020;117(5):8218-21.

9. Nguyen T, Bang DD, Wolff A. 2019 Novel coronavirus disease (COVID-19): paving the road for rapid detection and point-ofcare diagnostics. Micromachines. 2020;11(3):8218-21.

10. Zhao VXT, Wong TI, Zheng XT, Tan YN, Zhou X. Colorimetric biosensors for point-of-care virus detections. Mater Sci Energy Technol. 2020;3:237-49.

11. Nikaeen G, Abbaszadeh S, Yousefinejad S. Application of nanomaterials in treatment, anti-infection and detection of coronaviruses. Nanomedicine. 2020;15(15):1501-12.

12. Tripathi RM, Chung SJ. Phytosynthesis of palladium nanoclusters: an efficient nanozyme for ultrasensitive and selective detection of reactive oxygen species. Molecules. 2020;25(15):3349.

13. Tripathi RM, Ahn D, Kim YM, Chung SJ. Enzyme mimetic activity of $\mathrm{ZnO}-\mathrm{Pd}$ nanosheets synthesized via a green route. Molecules. 2020;25(11):2585.

14. Choi Y, Hwang JH, Lee SY. Recent trends in nanomaterialsbased colorimetric detection of pathogenic bacteria and viruses. Small Methods. 2018;2(4):1700351.

15. Kumar A, Boruah BM, Liang XJ. Gold nanoparticles: Promising nanomaterials for the diagnosis of cancer and HIV/AIDS. J Nanomater. 2011;17:1687-4110.

16. Somvanshi SB, Kharat PB, Saraf TS, Somwanshi SB, Shejul SB, Jadhav KM. Multifunctional nano-magnetic particles assisted viral RNA-extraction protocol for potential detection of COVID19. Mater Res Innov. 2020;25(3):169-74.

17. Tripathy S, Singh SG. Label-free electrochemical detection of DNA hybridization: a method for COVID-19 diagnosis. Trans Indian Natl Acad Eng. 2020. https://doi.org/10.1007/ s41403-020-00103-z.

18. Hedde PN, Abram TJ, Jain A, Nakajima R, Assis RRd, Pearce T, Jasinskas A, Toosky MN, Khan S, Felgner PL, Gratton E, Zhao W. A modular microarray imaging system for highly specific COVID-19 antibody testing. Lab Chip. 2020;20(18):3283-476.

19. Broughton JP, Deng X, Yu G, Fasching CL, Servellita V, Singh J, Miao X, Streithorst JA, Granados A, Gonzalez AS, Zorn K, Gopez A, Hsu E, Gu W, Miller S, Pan CY, Guevara H, Wadford DA, Chen JS, Chiu CY. CRISPR-Cas12-based detection of SARS-CoV-2. Nat Biotechnol. 2020;38(7):870-4.

20. Park SE. Epidemiology, virology, and clinical features of severe acute respiratory syndrome - coronavirus-2. Clin Exp Pediatr. 2020;63(4):119-24. 
21. Zhou P, Yang XL, Wang XG, Hu B, Zhang L, Zhang W, Si HR, Zhu Y, Li B, Huang CL, Chen HD, Chen J, Luo Y, Guo H, Jiang RD, Liu MQ, Chen Y, Shen XR, Wang X, Zheng XS, Zhao K, Chen QJ, Deng F, Liu LL, Yan B, Zhan FX, Wang YY, Xiao GF, Shi ZL. A pneumonia outbreak associated with a new coronavirus of probable bat origin. Nature. 2020;579(7798):270-3.

22. Zu ZY, Jiang MD, Xu PP, Chen W, Ni QQ, Lu GM, Zhang LJ. Coronavirus Disease 2019 (COVID-19): a perspective from China. Radiology. 2020;296(2):E15-25.

23. Sun J, He WT, Wang L, Lai A, Ji X, Zhai X, Li G, Suchard MA, Tian J, Zhou J, Veit M, Su S. COVID-19: epidemiology, evolution, and cross-disciplinary perspectives. Trends Mol Med. 2020;26(5):483-95.

24. Suganthan N. COVID-19. Jaffna Med J. 2019;31(2):3-8.

25. Jin Y, Yang H, Ji W, Wu W, Chen S, Zhang W, Duan G. Virology, epidemiology, pathogenesis, and control of COVID-19. Viruses. 2020;12(4):372.

26. Lai CC, Shih TP, Ko WC, Tang HJ, Hsueh PR. Severe acute respiratory syndrome coronavirus 2 (SARS-CoV-2) and coronavirus disease-2019 (COVID-19): the epidemic and the challenges. Int J Antimicrob Agents. 2020;55(3): 105924.

27. Ibrahim IM, Abdelmalek DH, Elshahat ME, Elfiky AA. COVID19 spike-host cell receptor GRP78 binding site prediction. J Infect. 2020;80(5):554-62.

28. Kong R, Yang G, Xue R, Liu M, Wang F, Hu J, Guo X, Chang S. COVID-19 Docking Server: a meta server for docking small molecules, peptides and antibodies against potential targets of COVID-19. Bioinformatics. 2020;36(20):5109-11.

29. Yan R, Zhang Y, Li Y, Xia L, Guo Y, Zhou Q. Structural basis for the recognition of SARS-CoV-2 by full-length human ACE2. Science. 2020;367(6485):1444-8.

30. Tang YW, Schmitz JE, Persing DH, Stratton CW. Laboratory diagnosis of COVID-19: current issues and challenges. J Clin Microbiol. 2020;58(6):e00512-e520.

31. Tahamtan A, Ardebili A. Real-time RT-PCR in COVID-19 detection: issues affecting the results. Expert Rev Mol Diagn. 2020;20(5):453-4.

32. Liu W, Liu L, Kou G, Zheng Y, Ding Y, Ni W, Wang Q, Tan L, Wu W, Tang S, Xiong Z, Zheng S. Evaluation of nucleocapsid and spike protein-based enzyme-linked immunosorbent assays for detecting antibodies against SARS-CoV-2. J Clin Microbiol. 2020;58(6):e00461-e520.

33. Yu F, Yan L, Wang N, Yang S, Wang L, Tang Y, Gao G, Wang S, Ma C, Xie R, Wang F, Tan C, Zhu L, Guo Y, Zhang F. Quantitative detection and viral load analysis of SARS-CoV-2 in infected patients. Clin Infect Dis. 2020;71(15):793-8.

34. Giulietti A, Overbergh L, Valckx D, Decallonne B, Bouillon R, Mathieu C. An overview of real-time quantitative PCR: applications to quantify cytokine gene expression. Methods. 2001;25(4):386-401.

35. Qamar MTu, Alqahtani SM, Alamri MA, Chen LL. Structural basis of SARS-CoV-2 3CLpro and anti-COVID-19 drug discovery from medicinal plants. J Pharm Anal. 2020;10(4):313-9.

36. Chu H, Chan JFW, Yuen TTT, Shuai H, Yuan S, Wang Y, Hu B, Yip CCY, Tsang JOL, Huang X, Chai Y, Yang D, Hou Y, Chik KKH, Zhang X, Fung AYF, Tsoi HW, Cai JP, Chan WM, Ip JD, Chu AWH, Zhou J, Lung DC, Kok KH, To KHW, Tsang OTY, Chan KH, Yuen KY. Comparative tropism, replication kinetics, and cell damage profiling of SARS-CoV-2 and SARS-CoV with implications for clinical manifestations, transmissibility, and laboratory studies of COVID-19: an observational study. Lancet Microbe. 2020;1(1):e14-23.

37. Wang X, Yao H, Xu X, Zhang P, Zhang M, Shao J, Xiao Y, Wang H. Limits of detection of 6 approved RT-PCR Kits for the Novel SARS-Coronavirus-2 (SARS-CoV-2). Clin Chem. 2020;66(7):977-9.
38. Shen M, Zhou Y, Ye J, Al-maskri AAA, Kang Y, Zeng S, Cai S. Recent advances and perspectives of nucleic acid detection for coronavirus. J Pharm Anal. 2020;10(2):97-101.

39. Campbell S, Landry ML. Rapid microbial antigen tests. Adv Tech Diagnostic Microbiol. 2018. https://doi.org/10.1007/ 978-3-319-33900-9_5.

40. Woo PCY, Lau SKP, Chen Y, Wong EYM, Chan KH, Chen H, Zhang L, Xia N, Yuen KY. Rapid detection of MERS coronavirus-like viruses in bats: Pote1ntial for tracking MERS coronavirus transmission and animal origin article. Emerg Microbes Infect. 2018;7(1):1-7.

41. Plourde AR, Bloch EM. A literature review of zika virus. Emerg Infect Dis. 2016;22(7):1185-92.

42. Wong SJ, Furuya A, Zou J, Xie X, Dupuis AP, Kramer LD, Shi PY. A multiplex microsphere immunoassay for Zika virus diagnosis. EBioMedicine. 2017;19:136-40.

43. Amini A, Varsaneux O, Kelly H, Tang W, Chen W, Boeras DI, Falconer J, Tucker JD, Chou R, Ishizaki A, Easterbrook P, Peeling RW. Diagnostic accuracy of tests to detect hepatitis B surface antigen: a systematic review of the literature and metaanalysis. BMC Infect Dis. 2017;17:698.

44. Gavin PJ, Thomson RB. Review of rapid diagnostic tests for influenza. Clin Appl Immunol Rev. 2003;4(4):268-75.

45. Casillas AM, Nyamathi AM, Sosa A, Wilder CL, Sands H. A Current review of Ebola Virus: pathogenesis, clinical presentation, and diagnostic assessment. Biol Res Nurs. 2003;4(4):268-75.

46. Broadhurst MJ, Brooks TJG, Pollock NR. Diagnosis of ebola virus disease: past, present, and future. Clin Microbiol Rev. 2016;29:773-93.

47. Santiago I. Trends and innovations in biosensors for COVID-19 mass testing. ChemBioChem. 2020;21(20):2880.

48. Cheng MS, Toh CS. Novel biosensing methodologies for ultrasensitive detection of viruses. Analyst. 2013;138(21):6219-29.

49. Vigneshvar S, Sudhakumari CC, Senthilkumaran B, Prakash H. Recent advances in biosensor technology for potential applications - an overview. Front Bioeng Biotechnol. 2016;4:11.

50. Roh C, Jo SK. Quantitative and sensitive detection of SARS coronavirus nucleocapsid protein using quantum dots-conjugated RNA aptamer on chip. J Chem Technol Biotechnol. 2011;86(12):1475-9.

51. Priyadarshini E, Pradhan N. Gold nanoparticles as efficient sensors in colorimetric detection of toxic metal ions: a review. Sens Actuators B Chem. 2017;238:888-902.

52. Huang C, Wen T, Shi FJ, Zeng XY, Jiao YJ. Rapid detection of IgM antibodies against the SARS-CoV-2 virus via colloidal gold nanoparticle-based lateral-flow assay. ACS Omega. 2020;5(21):12550-6.

53. Chen Z, Zhang Z, Zhai X, Li Y, Lin L, Zhao H, Bian L, Li P, Yu $\mathrm{L}, \mathrm{Wu}$ Y, Lin G. Rapid and sensitive detection of anti-SARSCoV-2 IgG, using lanthanide-doped nanoparticles-based lateral flow immunoassay. Anal Chem. 2020;92(10):7226-31.

54. Landfester K. Miniemulsion polymerization and the structure of polymer and hybrid nanoparticles. Angew Chemie Int Ed. 2009;48(25):4488-507.

55. Shirato K, Yano T, Senba S, Akachi S, Kobayashi T, Nishinaka T, Notomi T, Matsuyama S. Detection of Middle East respiratory syndrome coronavirus using reverse transcription loop-mediated isothermal amplification (RT-LAMP). Virol J. 2014;11(1):1-11.

56. Zhu X, Wang X, Han L, Chen T, Wang L, Li H, Li S, He L, Fu X, Chen S, Xing M, Chen H, Wang Y. Multiplex reverse transcription loop-mediated isothermal amplification combined with nanoparticle-based lateral flow biosensor for the diagnosis of COVID-19. Biosens Bioelectron. 2020;166: 112437.

57. González DQ, Merkoçi A. Nanoparticle-based lateral flow biosensors. Biosens Bioelectron. 2015;73:47-63. 
58. Tripathi RM. Chung SJ Biogenic nanomaterials: Synthesis, characterization, growth mechanism, and biomedical applications. J Microbiol Methods. 2019;157:65-80.

59. Lim TC, Ramakrishna S. A conceptual review of nanosensors. Zeitschrift Fur Naturforsch Sect A J Phys Sci. 2006;61(7-8):402-12.

60. Caygill RL, Blair GE, Millner PA. A review on viral biosensors to detect human pathogens. Anal Chim Acta. 2010;681(1-2):8-15.

61. Krejcova L, Hyne D, Adam V, Hubalek J, Kizek R. Electrochemical sensors and biosensors for influenza detection. Int $\mathrm{J}$ Electrochem Sci. 2012;7(11):10779-801.

62. Shan B, Broza YY, Li W, Wang Y, Wu S, Liu Z, Wang J, Gui S, Wang L, Zhang Z, Liu W, Zhou S, Jin W, Zhang Q, Hu D, Lin L, Zhang Q, Li W, Wang J, Liu H, Pan Y, Haick H. Multiplexed nanomaterial-based sensor array for detection of COVID-19 in exhaled breath. ACS Nano. 2020;14(9):12125-32.

63. Lamote K, Janssens E, Schillebeeckx E, Lapperre TS, De Winter BY, Van Meerbeeck JP. The scent of COVID-19: Viral (semi-) volatiles as fast diagnostic biomarkers? J Breath Res. 2020;14(4): 042001 .

64. Lu Y, Liang X, Niyungeko C, Zhou J, Xu J, Tian G. A review of the identification and detection of heavy metal ions in the environment by voltammetry. Talanta. 2018;178:324-38.

65. Gupta VK, Jain R, Radhapyari K, Jadon N, Agarwal S. Voltammetric techniques for the assay of pharmaceuticals-a review. Anal Biochem. 2011;408:179-96.

66. Costa-Rama E, Fernández Abedul MT. Adsorptive stripping voltammetry of indigo blue in a flow system. Lab Methods Dyn Electroanal. 2020;47-56.

67. Pumera M. Graphene in biosensing. Mater Today. 2011;14(7-8):308-15.

68. Zhu Z. An overview of carbon nanotubes and graphene for biosensing applications. Nano-Micro Lett. 2017;9(3):25. .

69. Krishnan SK, Singh E, Singh P, Meyyappan M, Nalwa HS. A review on graphene-based nanocomposites for electrochemical and fluorescent biosensors. RSC Adv. 2019;16:8778-881.

70. Seo G, Lee G, Kim MJ, Baek SH, Choi M, Ku KB, Lee CS, Jun S, Park D, Kim HG, Kim SJ, Lee JO, Kim BT, Park EC, Il KS. Rapid detection of COVID-19 Causative Virus (SARS-CoV-2) in Human nasopharyngeal swab specimens using field-effect transistor-based biosensor. ACS Nano. 2020;14(4):5135-42.

71. Layqah LA, Eissa S. An electrochemical immunosensor for the corona virus associated with the Middle East respiratory syndrome using an array of gold nanoparticle-modified carbon electrodes. Microchim Acta. 2019;186(4):224.

72. Bahadir EB, Sezgintürk MK. A review on impedimetric biosensors. Artif Cells Nanomed Biotechnol. 2016;44(1):248-62.

73. Sharma NK, Nain A, Singh K, Rani N, Singal A. Impedimetric sensors: principles, applications and recent trends. Int J Innov Technol Explor Eng. 2019;8(10):2278-3075.

74. Prodromidis MI. Impedimetric immunosensors-a review. Electrochim Acta. 2010;55(14):4227-33.

75. Steinmetz M, Lima D, Viana AG, Fujiwara ST, Pessôa CA, Etto RM, Wohnrath K. A sensitive label-free impedimetric DNA biosensor based on silsesquioxane-functionalized gold nanoparticles for Zika Virus detection. Biosens Bioelectron. 2019;141: 111351.

76. Huang J, Li Z, Liaw BY, Zhang J. Graphical analysis of electrochemical impedance spectroscopy data in Bode and Nyquist representations. J Power Sources. 2016;309:82-98.

77. Kumar S, Ahlawat W, Kumar R, Dilbaghi N. Graphene, carbon nanotubes, zinc oxide and gold as elite nanomaterials for fabrication of biosensors for healthcare. Biosens Bioelectron. 2015;70:498-503.

78. Rivas GA, Rubianes MD, Rodríguez MC, Ferreyra NF, Luque GL, Pedano ML, Miscoria SA, Parrado C. Carbon nanotubes for electrochemical biosensing. Talanta. 2007;74(3):291-307.
79. Ge C, Du J, Zhao L, Wang L, Liu Y, Li D, Yang Y, Zhou R, Zhao Y, Chai Z, Chen C. Binding of blood proteins to carbon nanotubes reduces cytotoxicity. Proc Natl Acad Sci USA. 2011;108(41):16968-73.

80. Camilli L, Passacantando M. Advances on sensors based on carbon nanotubes. Chemosensors. 2018;6(4):62.

81. Tam PD, Hieu NV, Chien ND, Le AT, Tuan MA. DNA sensor development based on multi-wall carbon nanotubes for labelfree influenza virus (type A) detection. J Immunol Methods. 2009;350(1-2):118-24.

82. Chandra P. Miniaturized label-free smartphone assisted electrochemical sensing approach for personalized COVID-19 diagnosis. Sens Int. 2020;1:10019.

83. Tripathi RM, Gupta RK, Singh P, Bhadwal AS, Shrivastav A, Kumar N, Shrivastav BR. Ultra-sensitive detection of mercury(II) ions in water sample using gold nanoparticles synthesized by Trichoderma harzianum and their mechanistic approach. Sens Actuators B Chem. 2014;204:637-46.

84. Tripathi RM, Park SH, Kim G, Kim DH, Ahn D, Kim YM, Kwon SJ, Yoon SY, Kang HJ, Chung SJ. Metal-induced redshift of optical spectra of gold nanoparticles: an instant, sensitive, and selective visual detection of lead ions. Int Biodeterior Biodegrad. 2019; $144: 104740$.

85. Ebralidze II, Laschuk NO, Poisson J, Zenkina OV. Colorimetric sensors and sensor arrays. Nanomater Des Sens Appl. 2019;1-39.

86. Jain PK, Huang X, El-Sayed IH, El-Sayed MA. Review of some interesting surface plasmon resonance-enhanced properties of noble metal nanoparticles and their applications to biosystems. Plasmonics. 2007;2:107-18.

87. Takemura K, Adegoke O, Takahashi N, Kato T, Li TC, Kitamoto N, Tanaka T, Suzuki T, Park EY. Versatility of a localized surface plasmon resonance-based gold nanoparticle-alloyed quantum dot nanobiosensor for immunofluorescence detection of viruses. Biosens Bioelectron. 2017;89(Pt2):998-1005.

88. Li M, Gou H, Al-Ogaidi I, Wu N. Nanostructured sensors for detection of heavy metals: a review. ACS Sustain Chem Eng. 2013;1(7):713-23.

89. Boken J, Khurana P, Thatai S, Kumar D, Prasad S. Plasmonic nanoparticles and their analytical applications: a review. Appl Spectrosc Rev. 2017;52(9):774-820.

90. Moitra P, Alafeef M, Dighe K, Frieman MB, Pan D. Selective naked-eye detection of SARS-CoV-2 mediated by $\mathrm{N}$ gene targeted antisense oligonucleotide capped plasmonic nanoparticles. ACS Nano. 2020;14(6):7617-27.

91. Lim EL, Yap CC, Teridi MAM, Teh CH, Mohd Yusoff ARB, Hj Jumali MH. A review of recent plasmonic nanoparticles incorporated P3HT: PCBM organic thin film solar cells. Org Electron. 2016;36:12-28.

92. Dawood AA. Mutated COVID-19 may foretell a great risk for mankind in the future. New Microbes New Infect. 2020;35: 100673.

93. Wang Y, Hu R, Lin G, Roy I, Yong KT. Functionalized quantum dots for biosensing and bioimaging and concerns on toxicity. ACS Appl Mater Interfaces. 2013;5(8):2786-99.

94. Fan Z, Li S, Yuan F, Fan L. Fluorescent graphene quantum dots for biosensing and bioimaging. RSC Adv. 2015;5:19773-89.

95. Gorshkov K, Susumu K, Chen J, Xu M, Pradhan M, Zhu W, Hu X, Breger JC, Wolak M, Oh E. Quantum dot-conjugated SARS-CoV-2 spike pseudo-virions enable tracking of angiotensin converting enzyme 2 binding and endocytosis. ACS Nano. 2020;14(9):12234-47.

96. Cao J, Sun T, Grattan KTV. Gold nanorod-based localized surface plasmon resonance biosensors: a review. Sens Actuators B Chem. 2014;195:332-51.

97. Lu X, Dong X, Zhang K, Han X, Fang X, Zhang Y. A gold nanorods-based fluorescent biosensor for the detection of 
hepatitis B virus DNA based on fluorescence resonance energy transfer. Analyst. 2013;138:642-50.

98. Cagnin S, Caraballo M, Guiducci C, Martini P, Ross M, Santaana M, Danley D, West T, Lanfranchi G. Overview of electrochemical DNA biosensors: New approaches to detect the expression of life. Sensors (Switzerland). 2009;9(4):3122-48.

99. Wang L, Li PCH. Microfluidic DNA microarray analysis: a review. Anal Chim Acta. 2011;678(1):12-27.

100. Jalandra R, Yadav AK, Verma D, Dalal N, Sharma M, Singh R, Kumar A, Solanki PR. Strategies and perspectives to develop SARS-CoV-2 detection methods and diagnostics. Biomed Pharmacother. 2020;129:11044.

101. Shi R, Ma W, Wu Q, Zhang B, Song Y, Guo Q, Xiao W, Wang Y, Zheng W. Design and application of 60mer oligonucleotide microarray in SARS coronavirus detection. Chinese Sci Bull. 2003;48(12):1165-9.

102. Long WH, Xiao HS, Gu XM, Zhang QH, Yang HJ, Zhao GP, Liu JH. A universal microarray for detection of SARS coronavirus. J Virol Methods. 2004;121(1):57-63.

103. de Assis RR, Jain A, Nakajima R, Jasinskas A, Felgner J, Obiero JM, Adenaiye O, Tai S, Hong F, Norris PJ, Stone M, Simmons G, Bagri A, Schreiber M, Buser A, Holbro A, Battegay M, Hosimer P, Noesen C, Milton DK, Davies H, Corash LM, Busch MP, Felgner PL, Khan S, Prometheus Study Group. Analysis of SARS-CoV-2 antibodies in COVID-19 convalescent blood using a Coronavirus antigen microarray. Nat Commun. 2021;12(1):1-9. 